CZU: 635.65:631.526(4-015+560) https://doi.org/10.53040/gppb7.2021.97

\title{
FOOD LEGUMES BREEDING PROGRAM IN EASTERN MEDITERRANEAN REGION AND TURKEY
}

\author{
DÜRDANE Mart, MELTEM Türkeri \\ Eastern Mediterranean Agricultural Research Institute, Adana, Turkey \\ e-mail: durdanemart@yahoo.com
}

\begin{abstract}
Breeding is aimed to breed for varieties that are tolerant against disease, suitable for mechanized cultivation and harvest, and also offer them to the farmers as promising varieties. Since the purpose of legumes production is to obtain grain products of high yield and quality, developing suitable varieties for target regions where they will be grown is an important factor that needs to be considered. This breeding program aimed to develop new variety of recommended legumes varieties for different regions and will stimulate an increase in cultivation area.

In Turkey chickpea is traditionally sown in spring and subjected to drought and heat stresses. Chickpea can be sown in autumn with new cultivars but winter-sown chickpea cultivars are not available for highlands. Some abiotic stresses (drought, heat, freezing etc.) and some biotic stresses (ascochyta blight, Fusarium wilt, and weeds) are common and important stresses, whereas nutrient imbalance including salinity are localized challenges.

Lentil is usually traditionally sown in autumn and Central Anatolia green lentil, South Eastern Anatolia red lentil regions in Turkey.

As a result of Turkish food legume Program, 48 chickpea, 41lentil, 49 beans, 3 faba beans, 3 pea and 4 cowpea varieties were registered.
\end{abstract}

Key words: breeding variety registered, seed production 